\title{
Delayed A poptosis Post-Cadmium Injury in Renal Proximal Tubule Epithelial Cells
}

\author{
Lindsay J. Stinsona Alison J. Darmon ${ }^{a}$ b Lina Dagnino a,b S.J.A. D'Souza ${ }^{a, b}$ \\ Departments of aPharmacology and Toxicology, and bPaediatrics, University of Western Ontario, \\ Child Health Research Institute, London, Ont., Canada
}

\section{Key Words}

Cadmium • Epithelial cell injury · Mitogen-activated protein kinases. Apoptosis

\begin{abstract}
Background: Accumulation of the widespread environmental toxin cadmium (Cd) in the kidney results initially in proximal tubule dysfunction. Exposure to $\mathrm{Cd}$ has been previously shown to induce apoptosis in LLC-PK (Lily Laboratory Culture, Porcine Kidney) cells, which are a model of proximal tubule epithelium. Hypothesis: We postulated that modulation of the components of the apoptotic pathway triggered by $\mathrm{Cd}$ is amenable to therapeutic intervention. Methods: We subjected confluent LLC-PK cells grown on two-compartment filters and on plastic to $\mathrm{Cd}(1-50 \mu \mathrm{M})$. Apoptosis and changes in components of the apoptotic pathway were measured by immunocytochemical and immunoblot analysis during the period of exposure and following $\mathrm{Cd}$ withdrawal. Results: Insignificant apoptosis was seen during exposure to $\mathrm{Cd}$ and immediately after removal of this metal. Two waves of apoptosis were noted 6 and $48 \mathrm{~h}$ after the $\mathrm{Cd}$ was removed from the apical compartment. The apoptosis $48 \mathrm{~h}$ post-Cd exposure was accompanied by a decrease in cellular ATP levels and transepithelial resis-
\end{abstract}

tance and preceded by an increase in p38 phosphorylation. Inhibition of p38 mitogen-activated protein kinase activity decreased the delayed apoptotic peak, without affecting the rate of recovery of the integrity of the renal epithelium. IGF-1 neither altered the delayed apoptosis nor facilitated the rate of recovery of the integrity of the renal epithelium. Conclusion: We demonstrate that following exposure to $\mathrm{Cd}$, renal epithelial cells undergo significant apoptosis, which appears to involve p38 and is not amenable to IGF therapy.

Copyright (C2003S. Karger AG, Basel

\section{Introduction}

Cadmium $(\mathrm{Cd})$ is a widespread toxin common in the food chain and in almost every environment [16, 34, 39]. Accumulation of $\mathrm{Cd}$ in the kidney results initially in proximal tubule dysfunction, followed by glomerular disease leading to chronic renal damage [39]. Exposure to Cd has been previously shown to induce apoptosis in LLC-PK (Lily Laboratory Culture, Porcine Kidney) cells [18-22, $31,43]$, which are a model of proximal tubule epithelium $[12,14]$. Although the precise mechanism of Cd-induced apoptosis in renal cells has yet to be elucidated, renal proximal tubular cell damage following a bolus dose of $\mathrm{Cd}$

\begin{tabular}{ll}
\hline KARGER & ( ) 2003 S. Karger AG, Basel \\
0250-8095/03/0231-0027\$19.50/0 \\
$\begin{array}{l}\text { Fax +4161306 1234 } \\
\begin{array}{l}\text { E-Mail karger@karger.ch } \\
\text { www.karger.com }\end{array}\end{array}$ & $\begin{array}{l}\text { Accessible online at: } \\
\text { www.karger.com/journals/ajn }\end{array}$
\end{tabular}

S.J.A. D'Souza or L. Dagnino

Department of Pharmacology and Toxicology, Medical Sciences Building

University of Western Ontario, London, Ont. N6A 5C1 (Canada)

Tel. +1 5196613417 (SJAD) or 4264 (LD), Fax +1 5196614051

E-Mail sjdsouza@uwo.ca or ldagnino@uwo.ca 
is associated with inhibition of mitochondrial respiration [42].

The proximal tubule epithelium of the nephron is also particularly susceptible to damage by other nephrotoxins and by ischemia-reperfusion injury, but displays a remarkable capacity to overcome the damage inflicted and to regenerate $[24,26,40]$. Depending on the intensity of the insult, renal epithelial cells may undergo apoptosis or necrosis [25]. Commonly, ischemia-reperfusion injury results in cellular ATP depletion [25]. A reduction in ATP levels in affected cells to less than $25 \%$ of normal values triggers necrosis. In contrast, reduction of ATP levels to $25-50 \%$ of normal values causes apoptosis [25].

Necrosis is irreversible and difficult to prevent. By contrast, the apoptotic pathway can potentially be modulated and/or neutralized to maintain cell viability [37]. The understanding of the mechanisms involved in apoptosis, regeneration and repair after acute renal failure remains rudimentary. However, mitogen-activated protein kinase (MAPK) activities, including those of JNK, p38 and ERK, are markedly enhanced after ischemia in vivo and chemical anoxia in vitro, suggesting that they play a role in cellular responses to hypoxic damage $[6,7,9$, $27,28,32,35]$. In addition, a number of growth factors and cytokines have been implicated in renal repair after ischemia [8, 27, 30].

Activation of the c-jun N-terminal kinase (JNK) and p38 families of MAPK is an early event in Cd-induced apoptosis in non-renal cell types [2, 3, 10, 11]. Others have suggested that whereas extracellular signal-regulated kinase (ERK) may help to maintain genome integrity and survival, p38 MAPK contributes to mitotic arrest and genome instability [1]. Importantly, others have suggested that insulin growth factor-1 (IGF-1) may play a role in modulating Cd nephrotoxicity [20].

To better understand the events that regulate initiation of apoptosis and regeneration, we subjected confluent LLC-PK cells to Cd-induced injury, and examined them during the recovery phase following Cd withdrawal. Under these conditions, there was insignificant apoptosis during exposure to $\mathrm{Cd}$ and immediately after removal of this metal. However, two waves of apoptosis occurred during the recovery phase. We postulated that modulation of the components of the apoptotic pathway triggered by $\mathrm{Cd}$ may be amenable to therapeutic intervention. We observed that inhibition of p38 activity decreased the delayed apoptotic peak, without affecting the rate of recovery of the integrity of the renal epithelium. In contrast, IGF-1 neither altered the delayed apoptosis nor facilitated repair of the monolayer.

\section{Methods}

\section{Cell Culture}

LLC-PK1 cells (American Type Culture Collection (Cl-101), Bethesda, Md., USA) were cultured in antibiotic-free Dulbecco's modified Eagle's Medium (DMEM) supplemented with 8\% fetal bovine serum (FBS) and passaged twice a week. For experiments, the cells were plated at a density of $10^{5}$ cells $/ \mathrm{cm}^{2}$ (confluent) on either plastic or on cell culture inserts (0.4 or $1.0 \mu M$; Becton-Dickinson) and cultured for 5 days, with daily growth medium changes. This ensured the establishment of a well-developed, polarized epithelial monolayer [12-15]. On day 6, the cells were washed twice with PBS and incubated in FBS-free DMEM for $12 \mathrm{~h}$ prior to the addition of $\mathrm{CdCl}_{2}(0-50 \mu M)$. Following a 12- or 24-hour incubation in the presence of $\mathrm{Cd}$, the epithelial monolayer was washed to 4-6 times with PBS to remove all extracellular Cd. The cells were allowed to recover by culture in normal growth medium for intervals indicated in individual experiments. To investigate the effects of IGF-1, LLC-PK1 cells were cultured in growth medium containing human IGF-1 (100 ng/ml, final; R\&D Systems). To investigate the effects of p38 inhibitor (Calbiochem) or PD98059 (Sigma), cells were treated for $4 \mathrm{~h}$ with the inhibitor immediately prior to the peak rise in caspase- 3 activity ( $24 \mathrm{~h}$ post-Cd). This short treatment time with the inhibitors ensured lack of cell death due to prolonged drug exposure.

\section{Cellular ATP Quantification}

Cellular ATP was measured by light emission using a luciferinluciferase assay kit (Sigma). Cells cultured in 12-well plates were treated with $\mathrm{CdCl}_{2}$ or with vehicle. Luminescence was measured on a Microtiter Plate Luminometer (Dynex Technologies). ATP levels were normalized to protein content, determined separately using Bradford assays (Bio-Rad).

\section{Apoptosis}

Apoptosis was assessed by examining nuclear morphology/chromatin condensation, and by measuring active caspase- 3 levels in immunoblots. To analyze nuclear morphology, cells were washed twice with PBS and their DNA was stained with Hoechst 33258 $\left(1 \mu \mathrm{g} / \mathrm{ml}\right.$; Sigma) for $10 \mathrm{~min}$ at $37^{\circ} \mathrm{C}$. Staining medium also included propidium iodide $(1 \mu \mathrm{g} / \mathrm{ml}$; Sigma) or Sytox Green $(1 \mu \mathrm{g} / \mathrm{ml}$; Molecular Probes, Portland, Oreg., USA). Cells were washed with PBS, fixed with $4 \%$ paraformaldehyde, and rinsed with PBS. The frequency of apoptosis or necrosis in ten random fields (300 cells/field, $400 \times$ magnification) was determined using an epifluorescence microscope (DMIRBE, Leica, Germany) attached to a cooled CCD camera (Orca II, Hammamatsu, Japan) driven by Openlab Digital Imaging Software (Improvision, UK).

\section{Atomic Absorption Spectroscopy}

LLC-PK1 cells treated with $\mathrm{CdCl}_{2}$ or with vehicle were collected, centrifuged for $10 \mathrm{~min}$ at room temperature and then re-suspended in $1 \mathrm{ml}$ of PBS. One tenth of the cells were used for protein determination. $1 \mathrm{ml}$ of nitric acid was added to the remaining sample and left overnight at room temperature to digest. The digested samples were then incubated for $3 \mathrm{~h}$ at $110^{\circ} \mathrm{C}$ and then diluted with doubledistilled water to a final volume of $2 \mathrm{ml}$. Metal content of the samples was quantified using a Varian Spectra A30 Atomic Absorption Spectrometer against certified standards. 
DNA Synthesis

[ $\left.{ }^{3} \mathrm{H}\right] \mathrm{d}$-thymidine (dThd) 5'-triphosphate incorporation into DNA was measured as previously described [5].

\section{Mitotic Index}

Hoechst 33258 stains all nuclei and allowed us to visualize mitotic nuclei. The mitotic index was calculated by expressing the number of mitotic nuclei as a percentage of the total nuclei in ten random fields ( 300 cells/field, $400 \times$ magnification).

\section{Immunoblot Analysis}

LLC-PK1 cells treated with $\mathrm{CdCl}_{2}$ or with vehicle were harvested and total cellular protein isolated as previously described [4, 5]. Protein concentrations were determined by the Bradford method (Bio$\mathrm{Rad})$. Lysates containing 50-100 $\mu \mathrm{g}$ protein/lane were resolved by denaturing polyacrylamide gel electrophoresis (SDS-PAGE) and transferred to PVDF membranes (Roche). Membranes were probed overnight at $4{ }^{\circ} \mathrm{C}$ with one of the following antibodies purchased from New England Biolabs: Active caspase-3 (Cat. \#9661), phosphoAKT (\#9271S), AKT (\#9272), phospho-p38 (\#9211S), p38 (\#9212), phospho-p42/44 (\#9101S) and p42/44 (\#9102). Following incubation with appropriate horseradish peroxidase-labeled secondary antibodies, proteins were visualized by enhanced chemiluminescence (ECL Plus, Amersham Pharmacia). All immunoblots were also probed for $\beta$-tubulin to normalize for protein loading. No significant differences in loading were noticed between samples in a given immunoblot using this method. Protein levels were estimated by densitometric analysis of the immunoblots (AlphaImager 1220 V5.5 Software, AlphaInnotech, Calif., USA). For blots with phospho-specific antibodies, normalization was also conducted with respect to total levels of the relevant protein.

Measurement of Transepithelial Resistance (TER)

LLC-PK1 cells were plated at confluence on polyethylene terephthalate (PET) membrane inserts $(1.0-\mu \mathrm{m}$ pore size) in 24-well HTS Multiwell Insert System plates (Becton-Dickinson). An EVOM Ohmmeter (World Precision Instrument, Fla., USA) was used to measure TER. Since the EVOM is sensitive to changes in media volume, we ensured that $500 \mu \mathrm{l}$ of medium was consistently added to each well (upper chamber) and $10 \mathrm{ml}$ was present in the common bottom plate. TER measurements were compared to (1) an untreated monolayer growth medium and (2) the initial TER of each monolayer prior to incubation with $\mathrm{CdCl}_{2}$.

\section{Data Analysis}

SPSS10 software was used for statistical analysis (Student's t and non-parametric Mann-Whitney). All data are expressed as mean \pm SEM. Significance was established at $\mathrm{p} \leq 0.5$.

\section{Results}

\section{Effects of Acute Cd Administration on LLC-PK Cells}

To begin to address the mechanisms of injury and regeneration of renal epithelial cell monolayer following $\mathrm{Cd}$ injury, we first established the extent and nature of damage to mature LLC-PK1 monolayers following exposure to that metal. Cells were plated at confluence, cul- tured for 5 days in normal growth medium, followed by $12 \mathrm{~h}$ of culture in serum-free medium to obtain a synchronized, quiescent cell population similar to proximal tubule epithelia. The cells were subsequently treated with various $\mathrm{CdCl}_{2}$ concentrations in serum-free medium, to avoid $\mathrm{Cd}$ sequestration by serum components. Immediately following $\mathrm{Cd}$ treatment, insignificant apoptosis was seen across a broad dose range (1-20 $\mu M$; fig. 1a). With higher Cd concentrations or longer treatments, substantial cell death ensued, largely due to necrosis (fig. 1a and data not shown).

To verify that the observed cell loss was due to $\mathrm{Cd}$ induced intracellular damage, we measured cellular $\mathrm{Cd}$ levels by atomic absorption spectroscopy. The results of these analyses demonstrated that the cellular Cd uptake after $12 \mathrm{~h}$ was proportional to extracellular $\mathrm{Cd}$ concentration (control: $0.01 \mu \mathrm{g} \mathrm{Cd} / \mu \mathrm{g}$ protein; $10 \mu M \mathrm{CdCl}_{2}: 0.7 \mu \mathrm{g}$ $\mathrm{Cd} / \mu \mathrm{g}$ protein).

$\mathrm{Cd}$ is a powerful inhibitor of mitochondrial function, thus we examined whether the Cd-induced cell death observed was correlated to changes in cellular ATP content. As shown in figure 1b, incubation of the cells with increasing $\mathrm{CdCl}_{2}$ concentrations induced a dose-dependent decrease in cellular ATP. Notably, ATP decreases greater than $40 \%$ were associated with increased necrosis, whereas the fraction of apoptotic cells was less sensitive to substantial ATP depletion.

\section{Response during Recovery from Cd-Induced Exposure}

To examine the recovery mechanisms subsequent to Cd-induced injury in LLC-PK1 cells, we determined the fraction of apoptotic cells at timed intervals after $\mathrm{Cd}$ removal. We postulated that the induction of apoptosis by $\mathrm{Cd}$ was a specific response that mediated removal of damaged cells to allow undamaged cells to recapitulate the epithelial monolayer. We observed a significant increase in apoptosis $3 \mathrm{~h}$ after $\mathrm{CdCl}_{2}$ removal, which was maintained over the first $24 \mathrm{~h}$ post-Cd (fig. $2 \mathrm{a}$ ). The apoptotic response of the cells appeared to be biphasic, with the second wave reaching maximum levels as high as 12-fold above those in untreated cultures at $48 \mathrm{~h}$ of recovery (fig. 2a).

Cells enter apoptosis asynchronously. Moreover, DNA fragmentation is not evident in all apoptotic cells. Active caspase- 3 was measured by immunoblot to complement the morphological assay. We observed a steady increase in active caspase- 3 levels as a function of time, reaching maximum values at $24-48 \mathrm{~h}$ of recovery (fig. 2a), correlating with the maximum apoptotic response observed at $48 \mathrm{~h}$ (fig. 2a). 


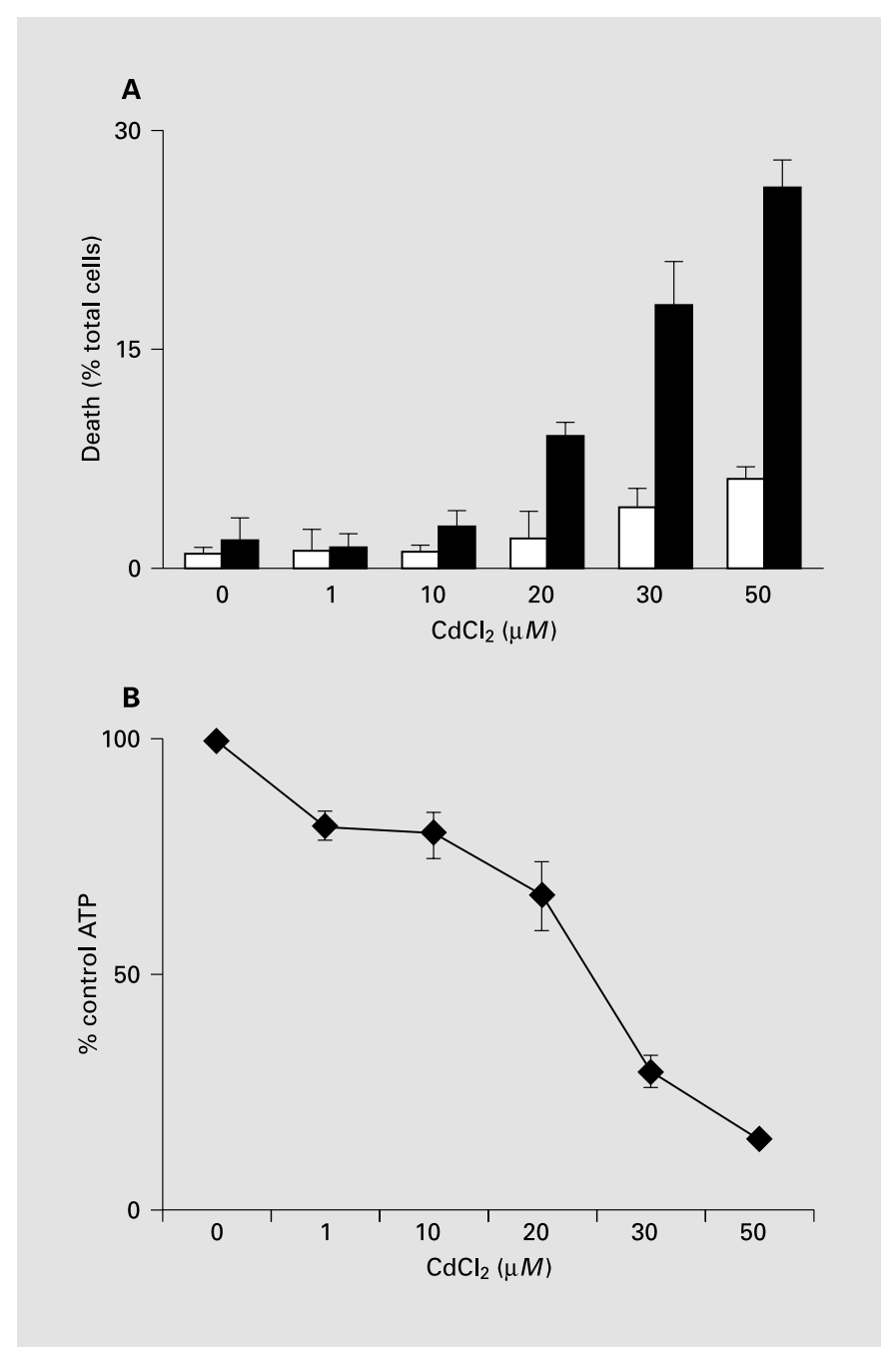

Fig. 1. Cell death and cellular ATP content as a function of $\mathrm{CdCl}_{2}$ concentration. A LLC-PK cells plated at confluence and grown for 5 days were serum starved for $12 \mathrm{~h}$ and then incubated with $\mathrm{CdCl}_{2}$ for 12 h. Cells were stained with Hoechst $33258(1 \mu \mathrm{g} / \mathrm{ml}$; Sigma $)$ and $/$ or propidium iodide ( $1 \mu \mathrm{g} / \mathrm{ml}$; Sigma) or Sytox Green $(1 \mu \mathrm{g} / \mathrm{ml}$; Molecular Probes) for $10 \mathrm{~min}$ at $37^{\circ} \mathrm{C}$. Each point represents the mean of 4 experiments of triplicate specimens, from which the frequency of apoptosis or necrosis (propidium iodide or Sytox Green-positive cells) in ten random fields ( 300 cells/field, $400 \times$ magnification) was determined using an epifluorescence microscope (DMIRBE, Leica) attached to a cooled CCD camera (Orca II, Hamamatsu) driven by Openlab Digital Imaging Software (Improvision). The error bars are the SEM. $\square=$ Serum starved; $\boldsymbol{\square}=\mathrm{CdCl}_{2}$. B Cellular ATP was measured by light emission using a luciferin-luciferase assay kit (Sigma). Luminescence was measured on a Microtiter Plate Luminometer (Dynex Technologies). ATP levels were normalized to protein content, determined separately using the Bradford assay (Bio-Rad). Each point represents the mean of 4 experiments of triplicate specimens and the SEM.
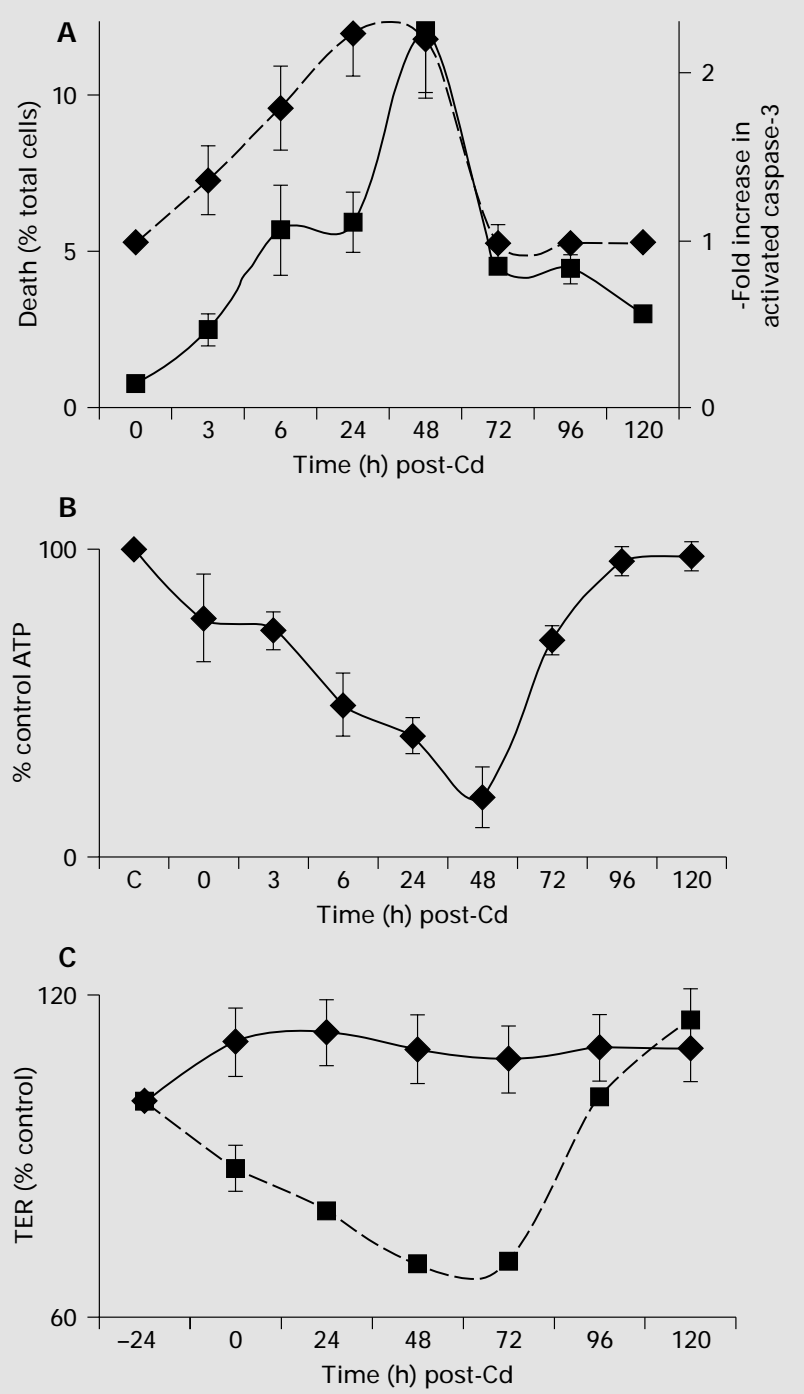

Fig. 2. Cell death, cellular ATP content and TER as a function of time following $\mathrm{CdCl}_{2}$ exposure. A LLC-PK cells plated at confluence and grown for 5 days were serum starved for $12 \mathrm{~h}$, incubated with $10 \mu M \mathrm{CdCl}_{2}$ for $12 \mathrm{~h}$ and then washed $(0 \mathrm{~h})$ and fed with normal medium augmented with $8 \%$ FBS. The number of apoptotic cells $(\boldsymbol{\square}$, solid line) was counted in 10 random fields (300 cells/field) in triplicate. Relative abundance (-fold increase) of active caspase- 3 $(\diamond$, broken line) was quantified by densitometric analysis of the immunoblots (AlphaImager 1220 V5.5 Software, AlphaInnotech). Loading was normalized to $\beta$-tubulin. B Cellular ATP was determined by the luciferin/luciferase assay and $\mathbf{C}$ TER using EVOM ohmmeter (World Precision Instrument) in LLC-PK cells plated at confluence, grown for 5 days after $12 \mathrm{~h}$ serum starvation and $12 \mathrm{~h}$ incubation with $10 \mu \mathrm{MCdCl}_{2}(0 \mathrm{~h})$ or after $12 \mathrm{~h}$ of serum starvation cell cultures $(\mathbf{C})$ and then after the cells were washed and fed with normal medium supplemented (3-120 h) with $8 \%$ FBS. Each point represents the mean of 4 experiments done in triplicate and SEM. 


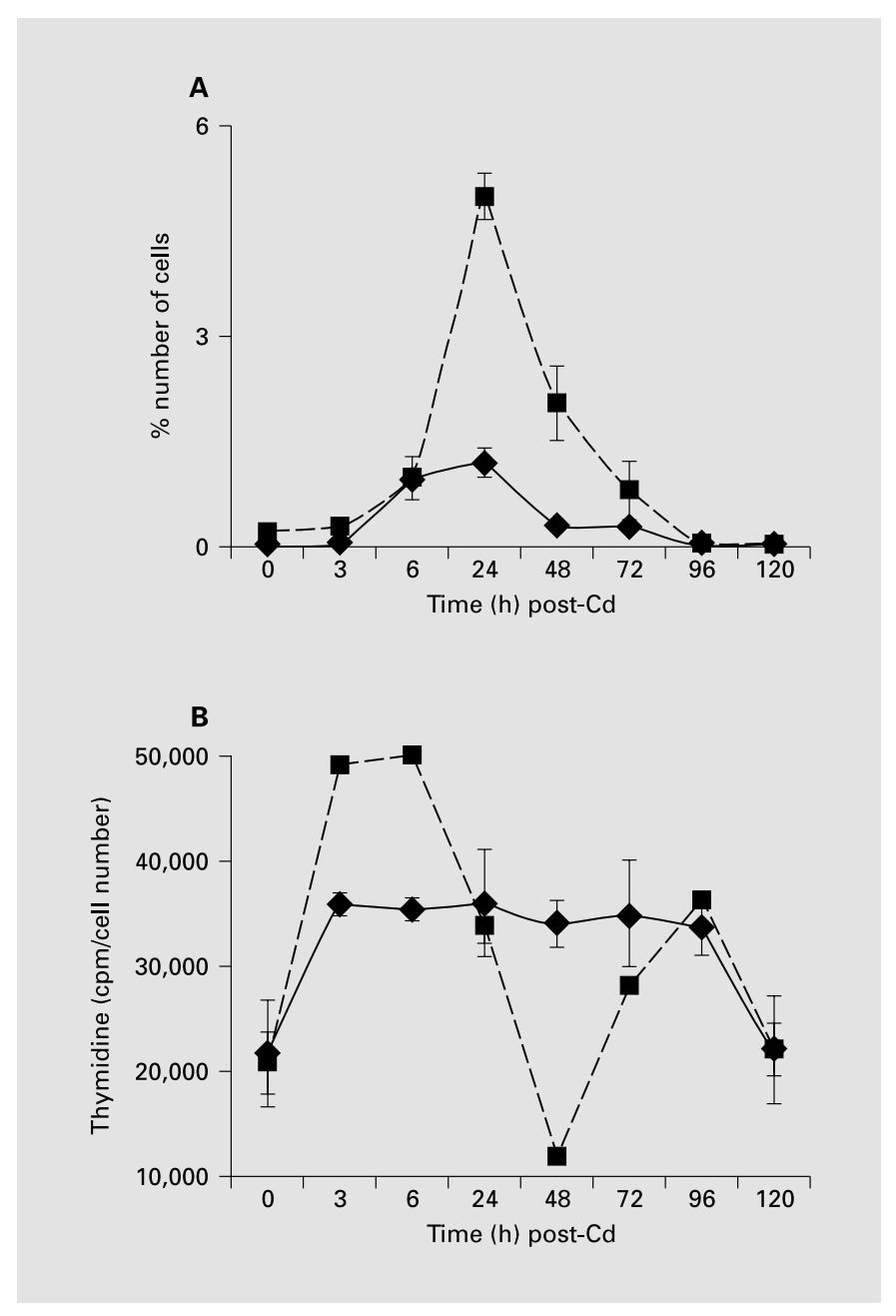

Fig. 3. Mitotic index and $\left[{ }^{3} \mathrm{H}\right]$-thymidine incorporation as a function of time following $\mathrm{CdCl}_{2}$ exposure. A The number of mitotic bodies was counted in 10 random fields ( 300 cells/field) and $\mathbf{B}\left[{ }^{3} \mathrm{H}\right]$-thymidine incorporation measured in triplicate in LLC-PK cells plated at confluence, grown for 5 days after $12 \mathrm{~h}$ serum starvation and $12 \mathrm{~h}$ incubation with $10 \mu M \mathrm{CdCl}_{2}(0 \mathrm{~h})(\boldsymbol{\square}$, broken line) or after $24 \mathrm{~h}$ of serum starvation cell cultures $(0 \mathrm{~h})(\diamond$, solid line) and then after the cells were washed and fed with normal medium supplemented (3-120 h) with $8 \%$ FBS. Each point represents the mean of 4 experiments done in triplicate and SEM.

The delayed apoptosis during the recovery phase suggest that $\mathrm{Cd}$ may be taken up, and stored intracellularly to interfere with various functions, including mitochondrial energy production. Hence, we determined if the relationship between decreased cellular ATP levels and onset of apoptosis was maintained during the recovery phase. Consistent with this concept, there was a time-dependent drop in cellular ATP levels to a nadir of $60 \%$ of untreated cells at $48 \mathrm{~h}$ of recovery, coinciding with the time of maxi- mum observed apoptosis (fig. 2b), and slowly recovered to normal levels over the next 3 days (fig. $2 b$ ).

We also measured the TER of the cell monolayer, which is a functional indicator of epithelial barrier function. Consistent with the observed changes in ATP levels and apoptosis, TER values decreased to $60 \%$ of control by $48 \mathrm{~h}$ of recovery. TER values remained low until $72 \mathrm{~h}$, and slowly reached normal levels at $120 \mathrm{~h}$ (fig. 2c). Thus, delayed $\mathrm{Cd}$ toxicity in vitro during the recovery phase results in cell loss, which in turn results in loss of barrier integrity, similar to renal Cd toxicity in vivo.

\section{Proliferative Responses of Cd-Treated LLC-PK1 Cells during the Recovery Phase}

According to the current understanding of renal epithelial regeneration, a nephrotoxic insult that results in cell death and loss of epithelial barrier integrity also induces mitogenic responses in the remaining cell population. Thus, viable cells will divide and migrate to cover denuded areas and re-establish renal function. To investigate whether Cd-induced damage would trigger cell division in the LLC-PK1 monolayers, we determined changes in DNA synthesis and mitotic index in untreated and in Cd-damaged cells. Addition of serum to control cells following a 24-hour incubation in serum-free medium resulted in a 1.5 -fold increase in $\left[{ }^{3} \mathrm{H}\right] \mathrm{dTh}$ incorporation into DNA, which was maintained for $96 \mathrm{~h}$. This increase likely stems from stimulation of quiescent cells to re-enter the cell cycle after serum starvation. The decrease in dThd incorporation noted $120 \mathrm{~h}$ following initial serum addition likely reflects the activation of contact-inhibition mechanisms (fig. 3a). Addition of serum to cells cultured in serum-free medium for $24 \mathrm{~h}$, and in the presence of $\mathrm{CdCl}_{2}$ for the last $12 \mathrm{~h}$, resulted in two waves of DNA synthesis within $120 \mathrm{~h}$ after serum addition. Specifically, a significantly greater, 2.5 -fold increase in $\left[{ }^{3} \mathrm{H}\right] \mathrm{dTh}$ incorporation into DNA was observed by $3 \mathrm{~h}$, a time course similar to that found in untreated cells (fig. 3a). This greater increase likely reflects a greater proportion of quiescent cells advancing to the S-phase of the cell cycle as a result of $\mathrm{Cd}$-induced damage and/or neighboring cell loss. The maximum increase in DNA synthesis between 3 and $6 \mathrm{~h}$ after serum addition was followed by a peak in the mitotic fraction 3- to 4-fold greater than in control cultures at $24 \mathrm{~h}$ (fig. 3b), thus mimicking the renal epithelial regenerative response in vivo. Thus, it appears that, in the recovery stage following Cd-induced injury, a fraction of the cell population is recruited back into the cell cycle, whereas another portion of the cells undergoes apoptosis. These two responses follow distinct time courses, with a 


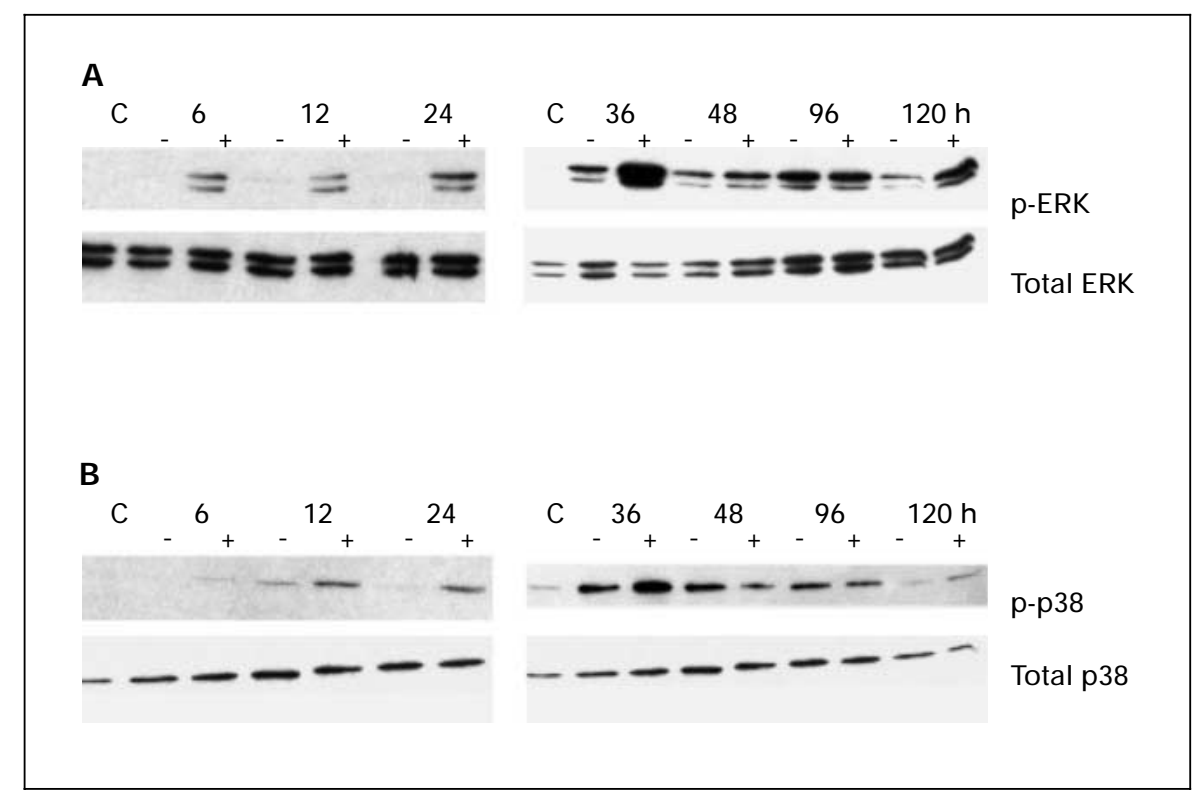

Fig. 4. Relative abundance of total and phosphorylated ERK and p38 as a function of time following $\mathrm{CdCl}_{2}$ exposure. A Representative immunoblots showing the relative abundance of total and phosphorylated ERK and B total and phosphorylated p38 in LLC-PK cells plated at confluence and grown for 5 days were serum starved for $12 \mathrm{~h}$, incubated with $10 \mu M \mathrm{CdCl}_{2}$ in serum-free medium for $12 \mathrm{~h}$ and then washed and fed with normal medium augmented with $8 \%$ FBS. Culturing cells for $24 \mathrm{~h}$ in the absence of serum did not abolish

peak in mitotic activity at $24 \mathrm{~h}$ of recovery, and maximum apoptosis at $48 \mathrm{~h}$.

\section{Regulation MAPK in Cd-Induced LLC-PK1 Cell Apoptosis}

The involvement of several MAP kinases in Cd injury and apoptosis in non-renal cells has been demonstrated. Further, activation of the MAPK cascade is an essential element of mitogenic responses to serum. Specifically, p38, JNK and ERK play an important role in these responses $[2,10]$. We assessed changes in the levels of phosphorylated kinases, which are a measure of their activation. Culturing cells for $24 \mathrm{~h}$ in the absence of serum did not abolish ERK42/44 expression, but levels of phosphorylated ERK in these cells were negligible in the absence or presence of $\mathrm{Cd}$ (fig. 4a). Addition of serum resulted in rapid transient activation of ERK p42/p44 within the first 60 min (data not shown), followed by a smaller, but sustained increase in phosphorylated ERKp42/p44 levels in cells cultured in the absence of $\mathrm{CdCl}_{2}$, as late as $96 \mathrm{~h}$, similar to ERK p42/44 abundance in other proliferating cells [pers. unpubl. data]. The reduction in mitotic index and
ERK42/44, but levels of phosphorylated ERK in these cells were negligible in absence or presence of Cd. Similar to total ERK p42/ p44, total levels of p38 did not appreciably change in Cd-treated or -untreated cultures upon serum addition. Phosphorylated p38 levels in untreated cultures did not change early after serum stimulation, but appeared to increase between 36 and $96 \mathrm{~h}$, and returned to barely detectable levels by $120 \mathrm{~h}$. The immunoblots are representative of 4 separate experiments.
DNA synthesis observed at $120 \mathrm{~h}$ in untreated cultures was accompanied by a reduction in phosphorylated ERK abundance. Those cells recovering from $\mathrm{CdCl}_{2}$ treatment also showed an early increase in phosphorylated ERK $\mathrm{p} 42 / \mathrm{p} 44$. In contrast to the untreated cells, these substantial increases in the levels of active ERKp42/p44 upon serum addition were maintained throughout the time course of analysis, reaching a maximum of about 8-fold above those observed prior to serum stimulation (fig. 4 a).

Similar to total ERK p42/p44, total levels of p38 did not appreciably change in Cd-treated or -untreated cultures upon serum addition (fig. 4b). Phosphorylated p38 levels in untreated cultures did not change early after serum stimulation, but appeared to increase between 36 and $96 \mathrm{~h}$, and returned to barely detectable levels by $120 \mathrm{~h}$, a time during which DNA synthesis and mitosis were minimal (fig. 4b). Phosphorylated p38 was undetectable in Cd-treated cultures early after serum addition, but increased by $6 \mathrm{~h}$ of recovery, to a maximum at $36 \mathrm{~h}$, just preceding the peak in cellular apoptosis (fig. $2 \mathrm{a}, 4 \mathrm{~b}$ ). Thus, Cd-induced injury differentially modulates the responses of two stress- and mitogen-modulated MAP kinases, like- 
Fig. 5. Effect of p38 and ERK inhibition on apoptosis and TER after $10 \mu M \mathrm{CdCl}_{2}$. LLCPK cells plated at confluence and grown for 5 days were serum starved for $12 \mathrm{~h}$, incubated with $10 \mu M \mathrm{CdCl}_{2}$ for $12 \mathrm{~h}$ and then washed and fed with normal medium augmented with $8 \%$ FBS. At $20 \mathrm{~h}$ after the $\mathrm{CdCl}_{2}$ was removed, either p38 inhibitor (p38I) or PD98059 was added to the media for $4 \mathrm{~h}$ and the number of apoptotic cells counted $(\mathbf{A}, \mathbf{C})$ and the relative abundance of active caspase-3 measured (B, D). In addition $(\mathbf{E})$, we measured the TER of the monolayer in the presence or absence of p38I $\left(\lambda, 24 \mathrm{~h}\right.$ serum starved, p38I: $\mu, 12 \mathrm{~h} \mathrm{CdCl}_{2}$, p38I) or PD98059 $(\sigma$, serum starved, PD98059: $\left.\Delta, 12 \mathrm{~h} \mathrm{CdCl}_{2}, \mathrm{p} 38 \mathrm{I}\right)$ in cells starved for $12 \mathrm{~h}$ and incubated with $10 \mu \mathrm{M}$ $\mathrm{CdCl}_{2}$ for $12 \mathrm{~h}(\theta)$ or serum starved for $24 \mathrm{~h}$ (v) prior to washing and refeeding with serum supplemented medium. Each point represents the mean of 4 experiments done in triplicate and SEM. ${ }^{*} \mathrm{p}<0.05$.
A

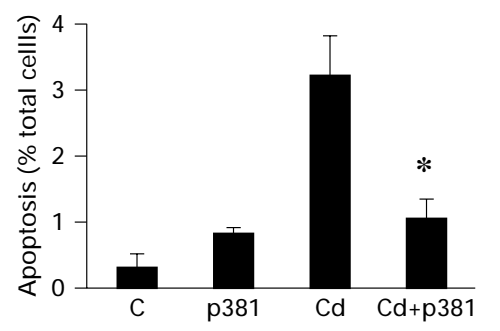

C

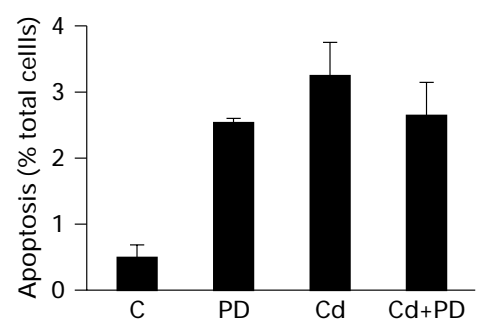

C $\quad$ p381 Cd Cd+p381

$\begin{array}{llll}5 & 10 \quad 5 \quad 10 \mu \mathrm{M}\end{array}$

_ _ _ _ - - Active caspase-3

$\ldots \ldots$ - $\ldots$-Tubulin

C PD Cd Cd+PD $2040 \quad 20 \quad 40 \mu \mathrm{M}$

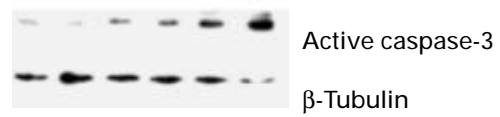

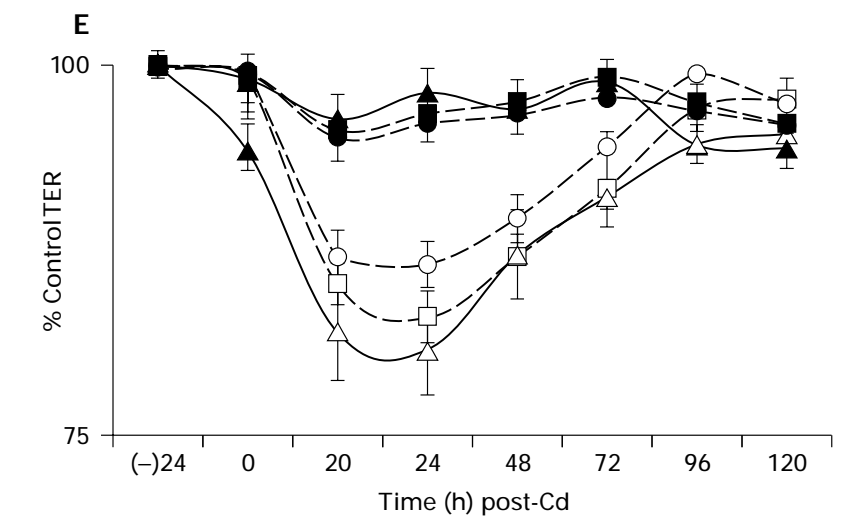

ly reflecting a differential role for these two proteins in the recovery phase following $\mathrm{Cd}^{2+}$-induced injury.

In this model, no alterations in total or phosphorylated JNK were seen in response to $\mathrm{Cd}$ (data not shown).

\section{Functional Role of p38 and ERK p42/p44 in}

$C d^{2+}$-Induced Delayed Apoptosis

Given that the most pronounced increments in phosphorylated p38 and in ERKp42/p44 occurred just prior to the second apoptotic wave during recovery, we examined the involvement of these kinases in the apoptotic response. LLC-PK1 cells to $\mathrm{CdCl}_{2}$ were treated as before, but included ERK or p38 inhibitors were included from 20 to $24 \mathrm{~h}$ post-Cd. We reasoned that, as both apoptosis and active caspase- 3 levels were substantial at that time, the use of MAPK inhibitors would provide information about their involvement in the apoptotic response. Control experiments using a 4-hour incubation with $\mathrm{p} 38 \mathrm{I}$ concentrations demonstrated to abolish p38 activity did not significantly alter the apoptotic cell fraction or active caspase-3 levels in our cultures (fig. 5a, b). This time of incubation was maintained in all subsequent experiments, as prolonged $\mathrm{p} 38 \mathrm{I}$ treatment can be cytotoxic by itself [10, 11]. The presence of $\mathrm{p} 38 \mathrm{I}$ during recovery in $\mathrm{Cd}^{2+}$-treated cultures resulted in significant decreases in apoptosis and active caspase-3 levels (fig. 5a, b).

We next investigated the effect on the apoptotic cascade of abrogating ERK p42/p44 activation by interfering 


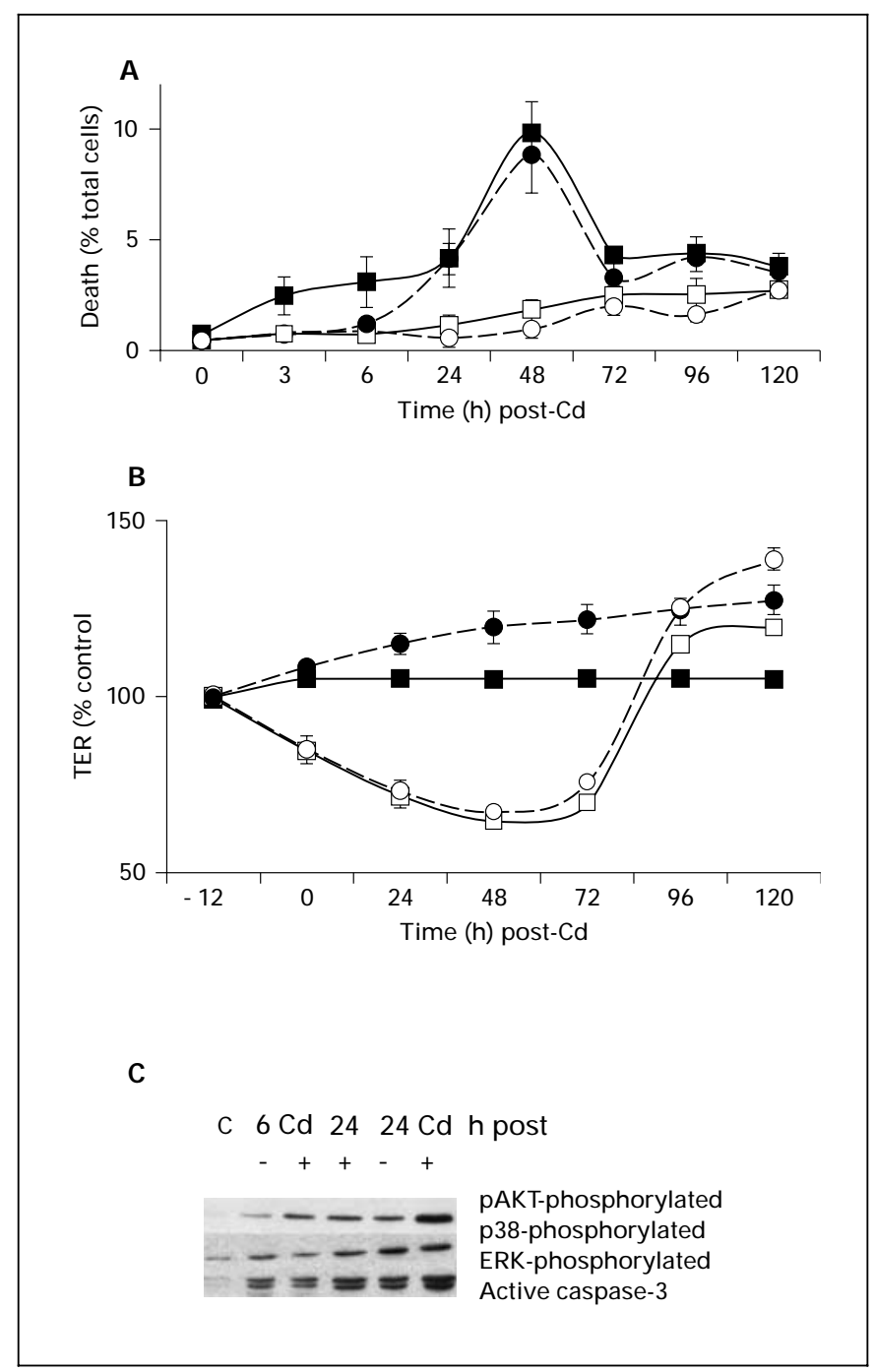

Fig. 6. Effect of IGF-1 on apoptosis and TER after $10 \mu M \mathrm{CdCl}_{2}$. A The number of apoptotic cells were counted in 10 random fields (300 cells/field) and B TER measured in triplicate in LLC-PK cells plated at confluence, grown for 5 days after $12 \mathrm{~h}$ serum starvation and $12 \mathrm{~h}$ incubation with $10 \mu M \mathrm{CdCl}_{2}(0 \mathrm{~h})(\square$, solid line) or after $24 \mathrm{~h}$ of serum starvation cell cultures $(0 \mathrm{~h})(\boldsymbol{\square}$, solid line) and then after the cells were washed and fed with normal medium supplemented (3-120 h) with 8\% FBS. Alternatively, the cells were replenished daily after $12 \mathrm{~h}$ of $10 \mu M \mathrm{CdCl}_{2}(\mathrm{O}$, broken line $)$ or $24 \mathrm{~h}$ of serum starvation $(\boldsymbol{O}$, broken line) with normal medium supplemented with IGF-1 $(100 \mathrm{ng} / \mathrm{ml})$. Each point represents the mean of 4 experiments done in triplicate and SEM. C Representative immunoblot of phosphorylated AKT, p38, ERK and activated caspase-3 after incubating cells treated for $12 \mathrm{~h}$ with $10 \mu M \mathrm{CdCl}_{2}$ or vehicle and then incubated for $24 \mathrm{~h}$ in normal medium supplemented with IGF-1 $(100 \mathrm{ng} / \mathrm{ml})$. with its phosphorylation with PD98059, an inhibitor of the ERK-activating enzyme MEK-1 [2, 3]. Incubating cells with PD98059 interfered with ERK p42/p44 phosphorylation, but did not significantly alter the apoptotic fraction in treated cells (fig. 5c), but increased activated caspase-3 levels $\mathrm{Cd}^{2+}$-treated cells (fig. $5 \mathrm{~d}$ ), suggesting that ERK fulfills a different function in this system, including the modulation of the elevated mitotic response during recovery from $\mathrm{Cd}^{2+}$ exposure.

As mentioned above, TER values were greatly reduced between 24 and $72 \mathrm{~h}$ after the onset of the recovery phase (fig. 2c, 5e). To measure the ability of p38I and PD98059 on monolayer functional regeneration, we assessed TER values of $\mathrm{Cd}^{2+}$-treated monolayers after $4 \mathrm{~h}$ of culture with these inhibitors. We found that neither p38I nor PD98059 altered the rate of recovery of TER when present during a single 4-hour incubation interval.

\section{IGF-1 and $C d^{2+}-$ Induced Apoptosis}

We determined whether IGF-1 afforded protection against the biphasic apoptotic response observed in $\mathrm{CdCl}_{2}$-injured cells. The results of these experiments showed that IGF-1 was able to prevent the earlier apoptotic wave at $6 \mathrm{~h}$ of recovery, but did not affect the second, more pronounced apoptotic phase at $48 \mathrm{~h}$ of recovery (fig. 6a), demonstrating that distinct mechanisms likely mediate the two waves of apoptosis. IGF-1 did not significantly alter the time course of recovery of TER function (fig. 6b). To confirm that IGF-1 signaling pathways were activated in the presence of this growth factor, we measured levels of phosphorylated PKB/AKT, a known IGF-1 target. We observed an increase in phosphorylated $\mathrm{PKB} / \mathrm{AKT}$ levels in cells treated with IGF-1 with or without prior incubation with $\mathrm{CdCl}_{2}$, demonstrating appropriate signaling through the IGF-1 receptor (fig. 6c). In addition, the presence of IGF-1 did not interfere with increments in either activated caspase- 3 or phosphorylated p38 levels associated with apoptosis, consistent with the proposed involvement of these proteins in $\mathrm{Cd}^{2+}$ induced apoptosis in LLC-PK1 cells (fig. 6c).

\section{Discussion}

The objective of this study was to examine the mechanisms underlying Cd-induced apoptosis in the course of recovery from an acute insult. With the advent of bettercharacterized cell lines and culture techniques, in vitro models are becoming more useful in toxicological research $[14,41]$. Pointedly, most of the previous work on 
$\mathrm{Cd}$ nephrotoxicity in vitro has focused on the acute event $[20,43]$. To the best of our knowledge, this is the first series of experiments to explore the recovery of an epithelial cell monolayer from an acute insult with $\mathrm{Cd}$ over a 5-day period. By extending the period of examination to 5 days post-exposure to $\mathrm{Cd}$, we demonstrated that $\mathrm{Cd}$ induces a prodigious amount of apoptosis via a p38dependent mechanism $48 \mathrm{~h}$ post-exposure, which may be associated with depletion in cellular ATP, induced by intracellular $\mathrm{Cd}$ disruption of mitochondrial respiration.

Whether $\mathrm{Cd}$ induces necrosis or apoptosis depends on the extracellular concentration and appears to reflect the degree of cellular ATP depletion induced by exposure to the metal. In vivo, renal proximal tubule epithelial cell damage following a bolus dose of Cd-metallothionein involves disruption of mitochondrial respiration, secondary to the accumulation of $\mathrm{Cd}$ [42]. Others have determined that ATP depletion to about 15-25\% of control represents a threshold that determines whether proximal tubule epithelial cells die by necrosis or apoptosis [25]. Consistent with these studies, high concentrations of $\mathrm{Cd}$ induced acutely severe drops in cellular ATP content, resulting in necrosis, whereas lower doses had lesser effects on cellular ATP and produced minimal necrosis and/or apoptosis.

The late prodigious apoptosis seen $48 \mathrm{~h}$ post-Cd is also associated with cellular ATP content. As previously reported [20], in vitro LLC-PK cells undergo apoptosis soon after removal of $\mathrm{Cd}$. Our data indicate that the immediate apoptosis is minor at best and that a more significant event takes place later in the recovery phase. In other experimental models of acute renal failure in vivo, apoptosis of renal tubule epithelial cells has been shown to occur in two distinct phases [23]. The first phase of apoptosis occurs between 12 and $48 \mathrm{~h}$ after the acute ischemic or nephrotoxic insult. The second phase of apoptosis occurs many days later, during the recovery phase. Tubular cell apoptosis occurring shortly after the acute insult probably contributes to tubular cell loss and the tubular dysfunction associated with injury. In contrast, the apoptosis associated with the recovery phase has been postulated to contribute to the remodeling of injured tubules. In the present study, the ongoing apoptosis seen upon withdrawal of $\mathrm{Cd}$ correlates with a continuing decrease in cellular ATP content. Thus, it is likely that a significant portion of $\mathrm{Cd}$ toxicity may be secondary to the lingering effects of intracellular $\mathrm{Cd}$ on mitochondria well after the withdrawal of the metal from the extracellular environment, but reflecting the first phase of injury following the acute nephrotoxic insult. It is likely that if we had contin- ued to follow our culture system past the 5 days, a second remodeling phase of apoptosis would have been apparent.

Recovery from a renal insult that causes cell loss is associated with epithelial cell proliferation and tubular remodelling. Consistent with this concept, we observed waves of DNA synthesis and mitotic activity in the recovering monolayers. Thus, it appears that, in the recovery stage following $\mathrm{Cd}$-induced injury, a fraction of the cell population is recruited back into the cell cycle, whereas another portion of the cells undergoes apoptosis. These two responses follow distinct time courses, with a peak in mitotic activity at $24 \mathrm{~h}$ of recovery, and maximum apoptosis at $48 \mathrm{~h}$.

The activation of $\mathrm{p} 38$ by $\mathrm{Cd}$ has been previously noted in non-renal cells $[2,3,10,11,17]$. At least two of these studies find that p38 activation is an early and specific regulatory event for the Cd-provoked apoptosis $[1,10]$. None of these investigators report a delayed activation of p38. Pointedly, the concentrations of $\mathrm{Cd}$ used by these studies to induce p38 activity acutely were 4 - to 20-fold greater than we used in our work, although the length of incubation was less $[1-3,10,11,17]$. However, it should be noted that LLC-PK cells have been previously shown to be more sensitive than other cells to $\mathrm{Cd}[31,43]$. Lower cytotoxic doses $(<80 \mu M)$ were reported to also activate JNK and ERK, but not p38 [2]. Although we note an increase in the abundance of phosphorylated ERK, neither native nor phosphorylated JNK was altered in our model.

A number of investigators have postulated that minimizing or inhibiting p38 activity or apoptosis may accelerate repair [10]. Whereas the later phase of apoptosis seen $48 \mathrm{~h}$ after the $\mathrm{Cd}$ pulse was associated with an increase in active $\mathrm{p} 38$, the early minimal rise in regulated cell death was not. Although judicious use of p38 inhibitor clearly blocks the secondary apoptotic wave, we see little improvement in the rate at which the epithelial monolayer re-establishes integrity. This may reflect the short period of inhibition or that other factors are involved in the regulating integrity of the epithelial monolayer. TER, which we used to measure epithelial integrity, is in fact a measure of the integrity of tight junctions. Tight junction recovery is a regulated process dependent on tyrosine phosphorylation [29]. Although Cd causes ATP depletion and changes in the cytoskeleton, the pattern of changes in the cytoskeleton and junctional proteins is different from that seen in chemical anoxia or ischemia [33, 36, 38, 43], suggesting that this metal may have other more significant effects. 
The inability of IGF-1 to inhibit the late apoptotic peak while blocking the earlier cell death is intriguing. Although much has been made of the anti-apoptotic properties of IGF-1 acting through PI3-K and AKT in ischemic injury, renal growth factors do not ameliorate apoptotic cell death induced by ATP depletion [25]. Importantly, IGF-1 inhibited the p38-independent apoptosis seen in the first $6 \mathrm{~h}$, when the ATP content was still $>75 \%$ of control. Clearly, the mechanism by which the cells undergo apoptosis in the second wave is either different from the first or simply not amenable to modification by AKT. We are in the process of delineating the upstream regulation and downstream targets of $\mathrm{p} 38$ activation during the second wave to better understand the regulated cell death.

\section{Acknowledgements}

This work was supported by the Toxic Substances Research Initiative, Health Canada, Grant No. 241 to SJAD and LD. SJAD is a Kidney Foundation of Canada Biomedical Research Scholar. LD is a Canadian Institutes of Health Research/Cancer Research Society Scholar. LJS was supported by an Ontario Graduate Scholarship in Science and Technology, 2000-2001.

\section{References}

1 Chao JI, Yang JL: Opposite roles of ERK and p38 mitogen-activated protein kinases in cadmium-induced genotoxicity and mitotic arrest. Chem Res Toxicol 2001;14:1193-1202.

2 Chuang SM, Wang IC, Yang JL: Roles of JNK, p38 and ERK mitogen-activated protein kinases in the growth inhibition and apoptosis induced by cadmium. Carcinogenesis 2000;21: 1423-1432.

3 Chuang SM, Yang JL: Comparison of roles of three mitogen-activated protein kinases induced by chromium (VI) and cadmium in nonsmall-cell lung carcinoma cells. Mol Cell Biochem 2001;222:85-95.

4 D'Souza S, Garcia-Cabado A, Yu F, Teter K, Lukacs G, Skorecki K, Moore HP, Orlowski J, Grinstein S: The epithelial sodium-hydrogen antiporter $\mathrm{Na}^{+} / \mathrm{H}^{+}$exchanger-3 accumulates and is functional in recycling endosomes. $\mathrm{J} \mathrm{Biol}$ Chem 1998;273:2035-2043

5 D’Souza SJ, Pajak A, Balazsi K, Dagnino L: $\mathrm{Ca}^{2+}$ and BMP-6 signaling regulate $\mathrm{E} 2 \mathrm{~F}$ during epidermal keratinocyte differentiation. J Biol Chem 2001;276:23531-23538.

6 De Silva H, Cioffi C, Yin T, Sandhu G, Webb

RL, Whelan J: Identification of a novel stressactivated kinase in kidney and heart. Biochem Biophys Res Commun 1998;250:647-652.

7 Di Mari JF, Davis R, Safirstein RL: MAPK activation determines renal epithelial cell survival during oxidative injury. Am J Physiol 1999;277:F195-F203

8 Donnahoo KK, Shames BD, Harken AH, Meldrum DR: Review article: the role of tumor necrosis factor in renal ischemia-reperfusion injury. J Urol 1999;162:196-203.

9 Faccio L, Chen A, Fusco C, Martinotti S, Bonventre JV, Zervos AS: Mxi2, a splice variant of p38 stress-activated kinase, is a distal nephron protein regulated with kidney ischemia. Am J Physiol 2000;278:C781-C790.
10 Galan A, Garcia-Bermejo ML, Troyano A, Vilaboa NE, de Blas E, Kazanietz MG, Aller P: Stimulation of $\mathrm{p} 38$ mitogen-activated protein kinase is an early regulatory event for the cadmium-induced apoptosis in human promonocytic cells. J Biol Chem 2000;275:1141811424.

11 Galan A, Troyano A, Vilaboa NE, Fernandez C, de Blas E, Aller P: Modulation of the stress response during apoptosis and necrosis induction in cadmium-treated U-937 human promonocytic cells. Biochim Biophys Acta 2001; 1538:38-46.

12 Gstraunthaler G, Gersdorf E, Fischer WM, Joannidis M, Pfaller W: Morphological and biochemical changes of LLC-PK1 cells during adaptation to glucose-free culture conditions. Ren Physiol Biochem 1990;13:137-153.

13 Gstraunthaler G, Seppi T, Pfaller W: Impact of culture conditions, culture media volumes and glucose content on metabolic properties of renal epithelial cell cultures. Are renal cells in tissue culture hypoxic? Cell Physiol Biochem 1999;9:150-172.

14 Gstraunthaler G, Steinmassl D, Pfaller W: Renal cell cultures: A tool for studying tubular function and nephrotoxicity. Toxicol Lett 1990;53:1-7.

15 Gstraunthaler GJ: Epithelial cells in tissue culture. Ren Physiol Biochem 1988;11:1-42.

$16 \mathrm{Hu} \mathrm{H}$ : Exposure to metals. Prim Care 2000;27: 983-996.

17 Hung JJ, Cheng TJ, Lai YK, Chang MD: Differential activation of $\mathrm{p} 38$ mitogen-activated protein kinase and extracellular signal-regulated protein kinases confers cadmium-induced HSP70 expression in 9L rat brain tumor cells. J Biol Chem 1998;273:31924-31931.

18 Ishido M, Homma ST, Leung PS, Tohyama C: Cadmium-induced DNA fragmentation is inhibitable by zinc in porcine kidney LLC-PK1 cells. Life Sci 1995;56:L351-L356.

19 Ishido M, Homma-Takeda S, Tohyama C, Suzuki T: Apoptosis in rat renal proximal tubular cells induced by cadmium. J Toxicol Environ Health A 1998;55:1-12.
20 Ishido M, Suzuki T, Adachi T, Kunimoto M: Zinc stimulates DNA synthesis during its antiapoptotic action independently with increments of an antiapoptotic protein, Bcl-2, in porcine kidney LLC-PK(1) cells. J Pharmacol Exp Ther 1999;290:923-928.

21 Ishido M, Tohyama C, Suzuki T: c-myc is not involved in cadmium-elicited apoptotic pathway in porcine kidney LLC-PK1 cells. Life Sci 1998;63:1195-1204.

22 Ishido M, Tohyama C, Suzuki T: Cadmiumbound metallothionein induces apoptosis in rat kidneys, but not in cultured kidney LLC-PK1 cells. Life Sci 1999;64:797-804.

23 Lieberthal W, Koh JS, Levine JS: Necrosis and apoptosis in acute renal failure. Semin Nephrol 1998;18:505-518.

24 Lieberthal W, Levine JS: Mechanisms of apoptosis and its potential role in renal tubular epithelial cell injury. Am J Physiol 1996;271: F477-F488.

25 Lieberthal W, Menza SA, Levine JS: Graded ATP depletion can cause necrosis or apoptosis of cultured mouse proximal tubular cells. Am J Physiol 1998;274:F315-F327.

26 Lieberthal W, Triaca V, Levine J: Mechanisms of death induced by cisplatin in proximal tubular epithelial cells: Apoptosis vs. necrosis. Am J Physiol 1996;270:F700-F708.

27 Liu ZX, Nickel CH, Cantley LG: HGF promotes adhesion of ATP-depleted renal tubular epithelial cells in a MAPK-dependent manner. Am J Physiol Renal Physiol 2001;281:F62F70.

28 Meldrum KK, Meldrum DR, Hile KL, Yerkes EB, Ayala A, Cain MP, Rink RC, Casale AJ, Kaefer MA: p38 MAPK mediates renal tubular cell TNF- $\alpha$ production and TNF- $\alpha$-dependent apoptosis during simulated ischemia. Am J Physiol 2001;281:C563-C570.

29 Meyer TN, Schwesinger C, Ye J, Denker BM, Nigam SK: Reassembly of the tight junction after oxidative stress depends on tyrosine kinase activity. J Biol Chem 2001;276:2204822055. 
30 Nigam S, Lieberthal W: Acute renal failure. III. The role of growth factors in the process of renal regeneration and repair. Am J Physiol Renal Physiol 2000;279:F3-F11.

31 Olabarrieta I, L'Azou B, Yuric S, Cambar J, Cajaraville MP: In vitro effects of cadmium on two different animal cell models. Toxicol In Vitro 2001;15:511-517.

32 Park KM, Kramers C, Vayssier-Taussat M, Chen A, Bonventre JV: Prevention of kidney ischemia/reperfusion-induced functional injury, MAPK and MAPK kinase activation, and inflammation by remote transient ureteral obstruction. J Biol Chem 2002;277:2040-2049.

33 Pearson CA, Prozialeck WC: E-cadherin, $\beta$ catenin and cadmium carcinogenesis. Med Hypotheses 2001;56:573-581.

34 Pinot F, Kreps SE, Bachelet M, Hainaut P, Bakonyi M, Polla BS: Cadmium in the environment: Sources, mechanisms of biotoxicity and biomarkers. Rev Environ Health 2000; 15:299_ 323.
35 Pombo CM, Bonventre JV, Avruch J, Woodgett JR, Kyriakis JM, Force T: The stress-activated protein kinases are major c-Jun aminoterminal kinases activated by ischemia and reperfusion. J Biol Chem 1994;269:2654626551.

36 Prozialeck WC, Lamar PC: Cadmium $\left(\mathrm{Cd}^{2+}\right)$ disrupts E-cadherin-dependent cell-cell junctions in MDCK cells. In Vitro Cell Dev Biol Anim 1997;33:516-526.

37 Rana A, Sathyanarayana P, Lieberthal W: Role of apoptosis of renal tubular cells in acute renal failure: Therapeutic implications. Apoptosis 2001;6:83-102.

38 Sabolic I, Herak-Kramberger CM, Brown D: Subchronic cadmium treatment affects the abundance and arrangement of cytoskeletal proteins in rat renal proximal tubule cells. Toxicology 2001;165:205-216.
39 Satarug S, Haswell-Elkins MR, Moore MR: Safe levels of cadmium intake to prevent renal toxicity in human subjects. Br J Nutr 2000;84: 791-802.

40 Sheridan AM, Bonventre JV: Cell biology and molecular mechanisms of injury in ischemic acute renal failure. Curr Opin Nephrol Hypertens 2000;9:427-434.

41 Steinmassl D, Pfaller W, Gstraunthaler G, Hoffmann W: LLC-PK1 epithelia as a model for in vitro assessment of proximal tubular nephrotoxicity. In Vitro Cell Dev Biol Anim 1995;31:94-106.

42 Tang W, Shaikh ZA: Renal cortical mitochondrial dysfunction upon cadmium metallothionein administration to Sprague-Dawley rats. J Toxicol Environ Health A 2001;63:221-235.

43 Zimmerhackl LB, Momm F, Wiegele G, Brandis $\mathrm{M}$ : Cadmium is more toxic to LLC-PK1 cells than to MDCK cells acting on the cadherin-catenin complex. Am J Physiol 1998;275: F143-F153. 